\title{
The Role of Orthodontics in the Management of Obstructive Sleep Apnea OSA in Children: Systematic Review
}

Norah Alotaibi ( $\sim$ noraa.mohammad@gmail.com )

Qassim University https://orcid.org/0000-0003-3896-8482

Amani alkhamees

King Abdulaziz Medical City

Rabia Bilal

Qassim University

Research article

Keywords: obstructive sleep apnea, children, oral appliances, mandibular advancement appliance, maxillary expansion.

Posted Date: August 12th, 2019

DOI: https://doi.org/10.21203/rs.2.12596/v1

License: (c) (i) This work is licensed under a Creative Commons Attribution 4.0 International License. Read Full License 


\section{Abstract}

Objective review the effectiveness of the use of different orthodontic oral appliance as a primary or adjective treatment of OSAS in children. methods: systemic search of online databases (PubMed, Cochrane Central Register of Controlled Trials (CENTRAL), international Registry Platform for ongoing trials and clinical trails.gov, Embase Ovid, Medline complete) for randomized control trail and nonrandomized prospective or retrospective clinical studies published in 2000-2019 that uses oral appliances for the treatment of OSA in children. Study selection was done by 2 reviews. Results 9 studies were included in the review. Based on the limited evidence oral appliances improve OSA in children measured by the reduction of AHI. Due to heterogeneity of included study designs and reported data meta-analysis was not possible. Limitation limited number of studies and study populations. High risk of bias. Conclusion oral appliances show a promising improvement in $\mathrm{AHI}$ and should be considered as a treatment option for OSA in children

\section{Background}

Obstructive sleep apnea (OSA) is defined by the American academy of sleep medicine AASM as "interrupted airflow despite persistent respiratory effort. It occurs several times every hour during sleep. Breathing continues but the airflow is blocked. This is due to the complete or partial collapse, and/or complete or partial obstructions, of the upper airway during sleep but not during wakefulness. With reduced airflow, gaseous exchange is impaired. Sleep is fragmented due to recurrent arousals"1.

The prevalence of OSA was estimated to be $1.2-5.7 \%$. the peak of OSA was observed at 2 periods. The first was in children from the ages of 2-8 years most commonly with adenio-tonsilar enlargement, the second peak was during adolescent in relation to obesity ${ }^{2,3}$. In pre pubertal children, the incidence of OSAS is similar in boys and girls. After puberty, OSA is more common in boys ${ }^{4}$.

OSA occurs when there is an imbalance between the factors that maintain a patent airway. These risk factors can be divided into factors that affect the airway collapsibility, factors that cause anatomical narrowing or a combination of both ${ }^{2}$. Factors that affect the airway collapsibility include inflammation, neuromuscular disorders, and decrease in upper respiratory tract muscle tone ${ }^{5}$. Factors that causes anatomical narrowing include adenotonsillar hypertrophy ${ }^{6}$, craniofacial anomalies (retrognathia, micrognathia, and midface hypoplasia), and macroglossia. A combination of these factors can be observes in some conditions like Down syndrome (pt. have large tongue and hypotonia) ${ }^{4}$.

The diagnosis of OSA in children is based on medical history, physical examination and confirmed with polysomnography PSG findings.

Children with OSA display symptoms that are mainly divided into daytime and nocturnal symptoms. Daytime symptoms include morning headache, daytime sleepiness, frequent airway infection. Nighttime 
symptoms include snoring, sweating, restless sleep ${ }^{3}$. Children with OSA also show some behavioral manifestation that ranges from aggression, hyperactivity, inattentiveness and pathological shyness ${ }^{7}$.

Physical examination should begin with general observation of child. The child weight and growth should be noted, other indications like mouth breathing, and nasal voice should be noted as well. In addition, the facial profile should be examined for craniofacial anomalies. Intra-oral examination to detect any abnormality that could lead to an obstruction of the airway including adenotonsillar hypertrophy, size of the tongue ${ }^{2}$.

PSG is considered the golden standard test for confirming the diagnosing of sleep apnea. It uses multi physiological parameters to diagnose OSA and other sleep disorders. The most used parameters for the diagnosis of OSA are apnea-hypopnea index (AHI), apnea index (Al), respiratory event-related arousals (RERAs), and respiratory disturbance index (RDI). AHI indicates the number of apneic and hypopneic events per hour of sleep. Apnea is defined as a complete interruption of airflow lasts at least two breaths, whereas hypopnea is defined as a $\geq 50 \%$ reduction in airflow with an arousal, awakening, or $\geq 3 \%$ desaturation for same durations. According to AASM the diagnosis of OSAS in children is defined as AHI index $>1^{8}$.

Treatment of OSA depends on the underlying cause and may include one or a combination of: Adenotonsillectomy, continues positive airway pressure, diet and medication, and use of oral appliances ${ }^{9}$. The use of oral appliances for the management of OSA was first introduced in 1902 by Dr. Pierre Robin. He fabricated an appliance by the name of "the monobloc" and prescribed it for children with hypotrophy of the mandible, which aimed to establish a normal spatial relationship of the maxilla and mandible ${ }^{10}$.

One of the most commonly used intraoral treatment modality is rapid maxillary expansion RME or slow maxillary expansion SME. RME devices are used for patients with constricted maxilla and posterior cross bite. It is used to increase the transvers width of maxilla increasing the palatal and retroplatal area. It also enlarges the nasal cavities, which in turn leads to less nasal resistance and promote nasal breathing ${ }^{11}$.

Stimulating the maxillary and mandibular growth was also used for the treatment of OSA in children with craniofacial anomalies. Forward reposition of the mandible was hypothesized to have a therapeutic effect by enlarging the upper airway (velopharynx) ${ }^{12}$.

The aim of this study is to review the effectiveness of the use of different orthodontic oral appliance as a primary or adjective treatment of OSA in children.

\section{Methods}

Preferred Reporting Items for Systematic review and Meta-Analysis (PRISMA) checklist was used as a template for this review. 
2.1 Protocol and registration: Not available

\subsection{Eligibility criteria:}

participants, interventions, comparators, and outcomes (PICO) was used to formulate the review objective and inclusion criteria

participant. children up to 18 years old.

interventions: any type of oral appliance as the primary treatment, use of oral appliance in conjunction with other treatment modalities, comparison between different types of oral appliances, comparison between oral appliances and other treatment modalities.

comparators: treatment vs control group, treatment vs different type of treatment, before vs after treatment.

Outcome: primary outcome reduction of $\mathrm{AHI}$, secondary outcomes: significant changes in other sleep parameters (e.g.: oxygen saturation, arousal index), craniodental changes, daytime and nocturnal symptoms.

Included studies: randomized controlled trials RCT, clinical studies both randomized and nonrandomized either retrospective or prospective.

due to the limited number of published RCT in the literature other types of clinical studies were included. pilot, preliminary and case report studies were not included due to limited sample size and higher risk of bias.

Studies publish in English from the year 2000 to May 2019.

\subsection{Exclusion criteria:}

Studies that includes adults in its sample, Studies that evaluate the use of other modalities in the treatment of OSA in children and Studies including a specific sample group: children with syndromes or systemic disorders.

\subsection{Information sources}


Systemic research of electronic databases: PubMed, Cochrane Central Register of Controlled Trials (CENTRAL), international Registry Platform for ongoing trials and clinical trails.gov, Embase Ovid, Medline complete.

RCT, NRCT, prospective and retrospective clinical studies that uses an oral appliance as a primary treatment or in conjunction with other treatment modalities and uses $\mathrm{AHI}$ to measure the effectiveness of the intervention were included in this review

Studies publish in English langue from 2000-May 2019

The last search was done on 27th of May 2019

The search was done independently in duplication by 2 reviewers (Norah Alotaibi and Amani Alkhamees) and any disagreement between the reviews was dissolved by the supervisor (Rabia Bilal).

\subsection{Search}

Search words were a combination of: "oral appliances/ oral device/ orthodontics/mandibular advancement appliance/ maxillary expansion" and "obstructive sleep apnea or obstructive sleep apnea or OSA" and "children/pediatric"

For PubMed the following limits were set: study type: controlled clinical trials, randomized control trails custom date range 01-01-2000 to 25-05-2019, language: English, Age: child: birth- 18 years

For Medline complete the following limits were set: Date (2000-2019), language: English, age: all child:018

For Cochrane Central Register of Controlled Trials (central) the following limits were set: year (20002019), Trails

For Embase Ovid the search was done using the multifield feature was used and the following limits were set: publication year (2000-current), Age group (All child 0 to 18), languages (English), publication type (clinical trial), publication types (clinical trials, ALL).

\subsection{Study selection}

Database search was done for possible studies, abstracts of the studies were screened for identification of eligible studies, Full text articles were obtained and assessed and a final list of included studies was made. 
This process was done independently and in duplication by 2 reviewers and any disagreement was resolved by the $3^{\text {rd }}$ reviewer

References were organized and managed using Mendeley desktop (version 1. 19. 4)

\subsection{Data collection process}

We developed a form based on the Cochrane Consumers and Communication Review Group's data extraction template and followed it for each study.

Two reviewers collected the data independently collected data was combined and compared for accuracy any discrepancies were solved by a third reviewer.

\subsection{Data items}

Data collected from the selected studies included: study design, study population (sample size, age, diagnosis, method of diagnosis, pre intervention records), intervention applied (type, duration of treatment and follow up), outcomes (primary outcome: changes in AHI, secondary outcome: changes in oxygen saturation, craniofacial and dental changes, reported symptoms changes)

\subsection{Risk of bias in individual studies}

Risk of bias assessment was done following The Cochrane Risk of Bias criteria. The assessment was done by two reviewers independently and in duplication and any discrepancies were resolved by the third reviewer.

\subsection{Summary measures}

primary outcome reduction of $\mathrm{AHI}$, secondary outcomes: other significant changes in sleep parameters, craniodental changes, daytime and nocturnal symptoms.

\subsection{Synthesis of results:}

Due to the difference in the included studies: study designs, lack of control groups in some studies, sample size, type of intervention used, duration of treatment, duration of follow up meta-analysis was not be conducted. 


\section{Results}

\subsection{Study selection:}

After the electronic search of the prespecified data basis (PubMed, Cochrane Central Register of Controlled Trials (CENTRAL), international Registry Platform for ongoing trials and clinical trails.gov, Embase Ovid, Medline complete) with the preset search terms and limits 228 studies were identified as for the first phase of screening. After screening the abstracts 218 studies were excluded for multiple reasons including but not limited to study type, study population: age, systemic health. Full text articles were obtained for the remaining 10 studies. Full text articles were read through by 2 reviewers 9 of which were included in the final review. 1 study was excluded at the final stage of eligibility screening due to: it included children with systemic disorders and syndrome and it used the term obstructive sleep apnea and sleep disordered breathing interchangeably.

Prisma flow diagram was used to show the process of study selection (figure 1)

\subsection{Study characteristics:}

\section{Methods:}

only one study was a randomized control trail ${ }^{13}$. Out of the remaining 8 studies 7 were non randomized prospective clinical studies ${ }^{14-20}$. One study had a more complicated design, it included 2 parts (2 objectives) one was prospective and the other was retrospective with 2 separate study population however we only included the prospective part due to the outcome type used in the retrospective section of the study (it didn't use AHI to measure the effectiveness of the treatment) ${ }^{21}$.

participants:

The included studies involved 272 subjects collectively. 19 of the participants dropped out or were excluded during the course of the treatment for multiple reasons including: failure to follow up, development of systemic disease, weight gain, moving out of the area etc.

All the participants were children under 18 yrs. All 272 participants were diagnosed with obstructive sleep apnea. 182 of the participants were also diagnosed with malocclusion and/or constriction of the maxillary arch and 70 children were also diagnosed with adenoid tonsillar enlargement.

One study included 20 healthy children as a control group ${ }^{18}$. Anthor study published in 2011 was a follow up study for a part of the study population (10 children) of a previously published study in $2007^{16,21}$.

Intervention: 
two of the included studies used oral appliances to reposition the mandible as their intervention. The $1^{\text {st }}$ study used a personalized oral appliance while the $2^{\text {nd }}$ study used a modified version of the monobloc appliance. Both appliances were used for 6 months duration ${ }^{13,18}$.

six studies reported the use of maxillary expansion as an intervention for obstructive sleep apnea in children as follows:

1- a study in 2004 by Pirelli P et al. used RME for 10-20 days for the active phase of the expansion and then for 6-12 months for the retention period ${ }^{17}$.

2- in 2007 a study by Villa MP et al. Used RME (leone Sesto Fiorentino-Florence) the active phase was 10 days or until the paleal cusp of the upper molar made a contact with the buccal cusp of the lower molar and the retention period was 12 months $^{16}$.

3- in 2011 a follow up study by Villa MP et al. included 10 out of 14 children that were included in the previous study and followed up with them after 36 months to evaluate the effectiveness and the stability of the intervention ${ }^{21}$.

4-in 2015 a study by Pirelli P et al. Used RME with a follow up for 12 years. It didn't give details on RME Duration ${ }^{14}$.

5- in 2015 a study by Villa MP et al. used RME on 40 children the active phase was until the paleal cusp of the upper molar made a contact with the buccal cusp of the lower molar and the retention period was 12 months ${ }^{20}$.

6- a study by Hoxha S et al in 2018 used a semi rapid maxillary expansion for 5 months ${ }^{19}$.

The last study divided its population into 3 group and compared the effectiveness of different interventions: adenotonsillectomy in the first group (cold dissection tonsillectomy and curettage of adenoid vegetation under direct vision via oral access) vs RME in the second group vs both treatments in the third group ${ }^{15}$.

\subsection{Outcome:}

Primary outcome: reduction of AHI

All studies used the $\mathrm{AHI}$ to measure the effectiveness of the treatment as their primary outcome. different types of oral interventions (oral repositioning appliance, maxillary expansion) showed a significant decrease in AHI (apnea hypopnea index). A summary of the primary outcomes is presented in table 1. 
Secondary outcome:

Reported secondary outcomes included significant change in sleep parameters (other than $A H I$ ), cranial/dental changes and improved clinical symptoms. A summary of the secondary outcomes is presented in table 2

\subsection{Risk of bias within studies}

For the risk of bias analysis, we followed The Cochrane Risk of Bias criteria for each included study. The risk of bias was high for all included studies due to lack of randomization and blinding. The results are summarized in table 3

\subsection{Results of individual studies}

Results of the included studies are summarized in the table 4

\section{Discussion}

\subsection{Summary of evidence:}

The aim of this study was to evaluate the use of oral appliances as a primary treatment or in conjunction with other treatment modalities for OSA in children. After a thorough search of the literature we found that the reported oral appliances used for OSA treatment in children were 1 of 2 main types: 1-appliences that position the mandible more anteriorly, 2-appliences that increase the transvers width of maxilla (maxillary expansion appliances) or a combination of both. We included studies that used oral appliance as the main treatment of OSA in children, studies that compare the use of oral appliance and other treatment modalities. Due to the limited number of randomized control trails that fit our inclusion criteria (only one was included) we also included non-randomized prospective or retrospective clinical studies. The risk of bias was found to be high for all included studies due to the non-randomization, lack of blinding and other reasons specific to the individual studies. The total number of included studies was 9 .

Maxillary expansion was the most commonly reported oral appliance/orthodontic treatment of choice for OSA in children. In this review we included 6 studies on maxillary expansion $17,16,21,14,20,19$. The studies vary slightly on the type of maxillary expansion (RME, SRME) duration of treatment and follow up but generally all use the same concept of increasing the transverse width of maxilla will therefore lead to an increase in the width of airway. All included studies on maxillary expansion reported significant reduction 
of AHI. Studies with longer follow up periods reported the stability of results and maxillary expansion induced by the orthodontic treatment ${ }^{21,14}$. Studies show that maxillary expansion to be more effective in patients with isolated maxillary constriction and malocclusion compared to patients with moderate to severe adenotonsillar hypertrophy or other respiratory disturbances. One study had specifically more improvement in patients with deep and retrusive bites compared to patients with cross-bite ${ }^{16}$.

2 studies reported the use of appliance that position the mandible anteriorly as a treatment of OSA in children ${ }^{13,18}$. This concept was first introduced in 1902 by Dr. Pierre Robin ${ }^{10}$. He fabricated an appliance by the name of "the monobloc". Both included studies reported reduction in the AHI and improved clinical symptoms. The first study used a personalized oral appliance to reposition the mandible the other one used a modified version of the monobloc appliance. Both studies reported a reduction of $A H I$ and improvement of the symptoms associated with OSA. One study also reported a surprising outcome of reducing tonsillar enlargement ${ }^{13}$.

\subsection{Limitations:}

Limited number of studies.

Small sample sizes.

Low quality evidence and high risk of bias.

\subsection{Conclusion:}

It's evident that OSA is multifactorial disorder. With that in mind, the use of oral appliances for the treatment should be considered only after taking the patient history, full physical examination, ENT assessment, intra and extra oral examination and orthodontic assessment.

The use of mandibular advancement appliances seems to more suitable for patients with skeletal II and a lower mandibular length.

The use of maxillary expansion has showed improvement in OSA for patients with constricted/narrow maxilla.

For complicated cases the use of oral appliances should be considered in conjunction with other treatment modalities. 
Due to limited number of evidence it is not possible to conclude that oral appliances are effective as a treatment for OSA

\section{Abbreviations}

AHI: apnea hypopnea index, OSA: obstructive sleep apnea, AASM: American academy of sleep medicine, PSG: Polysomnography, Al: apnea index, RERAs: respiratory event-related arousals, RDI: respiratory disturbance index, RME: rapid maxillary expansion, SRME: semi rapid maxillary expansion, SME: slow maxillary expansion, RCT: randomized controlled trials.

\section{Declarations}

\subsection{Ethics approval and consent to participate:}

ethical approval for the review was obtained from Dental Ethics Committee, Dental research center, Qassim University, Code \#:EA/407/2018

\subsection{Consent for publication:}

Not applicable

\subsection{Availability of data and material:}

All data is available upon request from the author.

\subsection{Competing interests:}

The authors declare no conflict of interest

\subsection{Funding:}

Dr. Alotaibi, Alkhamees and Bilal disclose no financial relationship relevant to this article. This commentary doesn't contain a discussion of unapproved/investitive use of commercial product/device.

\subsection{Authors' contributions:}


all authors have contributed in the review as follows: Norah alotaibi: study design, data collection, data analysis, writing the manuscript. Amani Alkhamees: study design, data collection and data analysis. Rabia Bilal: study design, overall supervision in data collection and analysis, writing the manuscript).

\subsection{Acknowledgements:}

Not applicable

\section{References}

1. Medicine. AA of S. The International Classification of Sleep Disorders: Diagnostic \& Coding Manual. Westchester, IL: American Academy of Sleep Medicine; 2005.

2. Bodenner KA, Jambhekar SK, Com G, Ward WL. Assessment and Treatment of Obstructive SleepDisordered Breathing. Clin Pediatr (Phila). 2014;53(6):544-548. doi:10.1177/0009922814527501

3. Chang SJ, Chae KY. Obstructive sleep apnea syndrome in children: Epidemiology, pathophysiology, diagnosis and sequelae. Korean J Pediatr. 2010;53(10):863-871. doi:10.3345/kjp.2010.53.10.863

4. DelRosso LM. Epidemiology and Diagnosis of Pediatric Obstructive Sleep Apnea. Curr Probl Pediatr Adolesc Health Care. 2016;46(1):2-6. doi:https://doi.org/10.1016/j.cppeds.2015.10.009

5. Tan H-L, Gozal D, Kheirandish-Gozal L. Obstructive sleep apnea in children: a critical update. Nat Sci Sleep. 2013;5:109-123. doi:10.2147/NSS.S51907

6. Galluzzi F, Pignataro L, Gaini RM, Garavello W. Drug Induced Sleep Endoscopy in the decision-making process of children with obstructive sleep apnea. Sleep Med. 2015;16(3):331-335.

doi:https://doi.org/10.1016/j.sleep.2014.10.017

7. Gottlieb DJ, Vezina RM, Chase C, et al. Symptoms of Sleep-Disordered Breathing in 5-Year-Old Children Are Associated With Sleepiness and Problem Behaviors. Pediatrics. 2003;112(4):870 LP 877. doi:10.1542/peds.112.4.870

8. Marcus CL, Brooks LJ, Draper KA, et al. Diagnosis and Management of Childhood Obstructive Sleep Apnea Syndrome. Pediatrics. 2012;130(3):576 LP - 584. doi:10.1542/peds.2012-1671

9. Brockbank JC. Update on pathophysiology and treatment of childhood obstructive sleep apnea syndrome. Paediatr Respir Rev. 2017;24:21-23. doi:https://doi.org/10.1016/j.prrv.2017.06.003

10. ROBIN P. GLOSSOPTOSIS DUE TO ATRESIA AND HYPOTROPHY OF THE MANDIBLE. JAMA Pediatr. 1934;48(3):541-547. doi:10.1001/archpedi.1934.01960160063005

11. Tsuiki S, Maeda K, Inoue Y. Rapid maxillary expansion for obstructive sleep apnea: a lemon for lemonade? J Clin Sleep Med. 2014;10(2):233. doi:10.5664/jcsm.3464

12. Chan ASL, Phillips CL, Cistulli PA. Obstructive sleep apnoea - an update. Intern Med J. 2010;40(2):102-106. doi:10.1111/j.1445-5994.2009.02069.x 
13. Villa MP, Bernkopf E, Pagani J, Broia V, Montesano M, Ronchetti R. Randomized Controlled Study of an Oral Jaw-Positioning Appliance for the Treatment of Obstructive Sleep Apnea in Children with Malocclusion. 2002;165:123-127. doi:10.1164/rccm2011031

14. Pirelli P, Saponara M, Guilleminault C. Rapid maxillary expansion ( RME ) for pediatric obstructive sleep apnea : a 12-year follow-up. Sleep Med. 2015;16(8):933-935. doi:10.1016/j.sleep.2015.04.012

15. Villa MP, Castaldo R, Miano S, et al. Adenotonsillectomy and orthodontic therapy in pediatric obstructive sleep apnea. 2014:533-539. doi:10.1007/s11325-013-0915-3

16. Villa MP, Malagola C, Pagani J, et al. Rapid maxillary expansion in children with obstructive sleep apnea syndrome: 12-month follow-up q. 2007;8:128-134. doi:10.1016/j.sleep.2006.06.009

17. Pirelli P, Saponara M, Guilleminault C, Biol D. Rapid Maxillary Expansion in Children with Obstructive Sleep Apnea Syndrome. 2004;27(4).

18. Cozza P, Polimeni A, Ballanti F. A modified monobloc for the treatment of obstructive sleep apnoea in paediatric patients. 2004;26(5):523-530.

19. Hoxha S, Kaya-sezginer E, Bakar-ates F, Köktürk O, Toygar-memiko U. Effect of semi-rapid maxillary expansion in children with obstructive sleep apnea syndrome: 5-month follow-up study. 2018:10531061.

20. Villa MP, Rizzoli A, Rabasco J, et al. Rapid maxillary expansion outcomes in treatment of obstructive sleep apnea in children. Sleep Med. 2015;16(6):709-716. doi:10.1016/j.sleep.2014.11.019

21. Villa MP, Rizzoli A, Miano S. Efficacy of rapid maxillary expansion in children with obstructive sleep apnea syndrome: 36 months of follow-up. 2011:179-184. doi:10.1007/s11325-011-0505-1

\section{Tables}

Table 1: Primary outcomes

\begin{tabular}{|c|c|c|c|}
\hline \multirow[t]{2}{*}{ Study } & \multirow[t]{2}{*}{ Type of intervention } & \multicolumn{2}{|c|}{ Mean AHI event/hr. } \\
\hline & & Before & After \\
\hline Villa MP et al. ${ }^{13}$ & Oral repositioning appliance & $7.1 \pm 4.6$ & $2.6 \pm 2.2$ \\
\hline Cozza et $\mathrm{al}^{18}$ & Modified monobloc & 7.88 & 3.66 \\
\hline Pirelli P et al ${ }^{17}$ & RME & $12.18 \pm 2.6$ & $0.4 \pm 1.1$ \\
\hline Villa MP et $\mathrm{al}^{16}$ & RME with $12 \mathrm{~m}$ follow up & $5.8 \pm 6.8$ & $1.5 \pm 1.6$ \\
\hline Villa MP et $\mathrm{al}^{21}$ & RME with 36 m follow up & $6.3 \pm 4.7$ & $2.3 \pm 1.7$ \\
\hline \multirow[t]{3}{*}{ Villa MP et ${ }^{15}$} & Adenotonsillectomy & $17.25 \pm 13.94$ & $1.8 \pm 1.82$ \\
\hline & $\mathrm{RME}$ & $5.81 \pm 6.05$ & $2.64 \pm 3.11$ \\
\hline & Both & $10.14 \pm 7.25$ & $0.88 \pm 0.95$ \\
\hline Pirelli P et $\mathrm{al}^{14}$ & RME with 12 yrs. follow up & $12.2 \pm 2.6$ & $0.3 \pm 0.9$ \\
\hline Villa MP et $\mathrm{al}^{20}$ & RME & $4.7 \pm 4.4$ & $1.6 \pm 1.4$ \\
\hline Hoxhas $\mathrm{S}$ et $\mathrm{al}^{19}$ & SRME with $5 \mathrm{~m}$ follow up & $2.5 \pm 1.12$ & $1.79 \pm 1.05$ \\
\hline
\end{tabular}

Table 2: secondary outcomes 


\begin{tabular}{|c|c|c|}
\hline study & $\begin{array}{c}\text { Type of } \\
\text { intervention }\end{array}$ & Secondary outcomes \\
\hline $\begin{array}{l}\text { Villa } \\
\text { MP et } \\
\text { al. }{ }^{13}\end{array}$ & $\begin{array}{l}\text { Oral repositioning } \\
\text { appliance }\end{array}$ & $\begin{array}{l}\text {-PSG showed significant reduction in AI in the treatment group after } 6 \\
\text { months } \\
\text {-reduction in symptoms: } \\
7 \text { out } 14 \text { patients of the treatment group ( } 50 \% \text { ) showed a reduced respiratory } \\
\text { score by at least } 2 \text { points and in the remaining } 7 \text { patients there was a } \\
\text { complete resolution of clinical symptoms (respiratory score=0, Brouillette } \\
\text { questionnaire). } \\
\text { However, the control group didn't show any changes in the clinical } \\
\text { symptoms. } \\
\text {-Tonsillar hypertrophy (> } 2 \text { clinical score) was reported in } 12 \text { out } 14 \text { (85.7\%) } \\
\text { patients in the treatment group at baseline and in } 7 \text { out of } 9 \text { ( } 77.8 \% \text { in the } \\
\text { control group. after } 6 \text { months, } 6 \text { out } 14 \text { children in the treatment group } \\
\text { showed reduction in Tonsillar hypertrophy while only one patient in the } \\
\text { control group reported similar outcome. }\end{array}$ \\
\hline $\begin{array}{l}\text { Cozza } \\
\text { et } \mathrm{al}^{18}\end{array}$ & Modified monobloc & $\begin{array}{l}\text {-Reduced daytime sleepiness and improved quality of sleep was observed } \\
\text { after } 6 \mathrm{~m} \text { of MM therapy in OSA group (ESS score reduced from } 15.2 \pm 4.9 \text { to } \\
7.1 \pm 2 \text { ) }\end{array}$ \\
\hline $\begin{array}{l}\text { Pirelli } \\
\text { P et } \\
\mathrm{al}^{17}\end{array}$ & RME & $\begin{array}{l}\text { Anterior rhinometry showed a decrease in nasal resistance with the absence } \\
\text { of pathological findings. } \\
\text { Anatomical changes in upper jaw and nasal septum including: } \\
\text {-expansion of maxilla and mandible with the mean cross-sectional increase of } \\
4.32 \pm .7 \mathrm{~mm} \\
\text { - increase upper molar distance }(3.89 \pm .3) \\
\text {-midpalate opening and inter incisive space opening }(2.97 \pm .2 \mathrm{~mm}) \\
\text {-mean increase in the nasal pyriform opening of } 1.3 \pm .3 \mathrm{~mm}\end{array}$ \\
\hline $\begin{array}{l}\text { Villa } \\
\text { MP et } \\
\mathrm{al}^{16}\end{array}$ & $\begin{array}{l}\text { RME with } 12 \mathrm{~m} \\
\text { follow up }\end{array}$ & $\begin{array}{l}\text {-OHI and arousal index OI also showed significant improvement ( } 3.1 \pm 3.2 \text { vs } \\
.9 \pm 1.3 \text { and } 17.2 \pm 3.5 \text { vs } 9.2 \pm 1.6 \text { respectively) } \\
\text {-mean maxillary expansion of } 3.7 \pm .7 \text { intercanine diameter and } 5 \pm 2.2 \text { in } \\
\text { premolar diameter } \\
\text {-significant decrease in the severity of the symptoms. Brouillette } \\
\text { questionnaire: mean clinical score improve from } 8.2 \pm 4 \text { vs } 4.2 \pm 2.9 \text {. }\end{array}$ \\
\hline $\begin{array}{l}\text { Villa } \\
\text { MP et } \\
\mathrm{al}^{21}\end{array}$ & $\begin{array}{l}\text { RME with } 36 \mathrm{~m} \\
\text { follow up }\end{array}$ & $\begin{array}{l}\text { At T1 (12 months after treatment): } \\
\text { the number of patients with tonsillar hypertrophy with clinical score (+3 and } \\
+4) \text { decreased scientifically from } 6 \text { to } 0 \text { out of } 10 \text { subjects. } \\
\text { - Brouillette questionnaire showed improved clinical symptoms (night time } \\
\text { symptoms: habitual snoring and apneas showed a significant decrease ( } 9 \text { vs } \\
4 \text { and } 8 \text { vs } 1 \text { respectively), daytime symptoms: sleepiness and oral breathing } \\
\text { also showed a significant decrease ( } 8 \text { vs } 2 \text { and } 7 \text { vs } 3 \text { respectively)) } \\
\text { At T2 ( } 24 \text { months after treatment): } \\
\text {-one patient presented with moderate tonsillar hypertrophy. } \\
\text { - Brouillette questionnaire showed improved clinical symptoms. }\end{array}$ \\
\hline Villa & Adenotonsillectomy & BMI, mean overnight saturation showed a significant increase from T0-T1 \\
\hline
\end{tabular}

Page $14 / 25$ 


\begin{tabular}{|c|c|c|}
\hline \multirow[t]{3}{*}{$\begin{array}{l}\text { MP } \\
\text { et }^{15}\end{array}$} & & $\begin{array}{l}(47.05 \pm 13.94 \text { to } 81.35 \pm 26.49 \text { and } 96.11 \pm 2.68 \text { to } 97.5 \pm 1.14) \text { and } \mathrm{AI} \\
\text { showed a significant decrease from T0-T1 }(20.87 \pm 5.66 \text { to } 14.5 \pm 6.51)\end{array}$ \\
\hline & $\mathrm{RME}$ & $\begin{array}{l}\text { mean overnight saturation and total sleep time showed significant increase } \\
\text { from T0-T1 }(96.56 \pm 1.47 \text { to } 97.42 \pm 1.84 \text { and } 6.64 \pm .89 \text { to } 7.47 \pm .92)\end{array}$ \\
\hline & Both & No secondary outcomes reported \\
\hline $\begin{array}{l}\text { Pirelli } \\
\text { P et } \\
\mathrm{al}^{14}\end{array}$ & $\begin{array}{l}\text { RME with } 12 \text { yrs. } \\
\text { follow up }\end{array}$ & $\begin{array}{l}\text { - an opening in the inter incisive space }(2.95 \pm .3 \mathrm{~mm} \text { ) was present } \\
\text {-a significant increase in SaO2 from } 78.9 \pm 8.6 \% \text { to } 95.1 \pm 1.9 \% \text {. } \\
\text {-complete resolution of clinical symptoms (ESS mean score } 3 \pm 1 \text { ) }\end{array}$ \\
\hline $\begin{array}{l}\text { Villa } \\
\text { MP et } \\
\mathrm{al}^{20}\end{array}$ & RME & $\begin{array}{l}\text {-significant reduction in AI from T0-T1 ( } 16.3 \pm 7.9 \text { to } 13.2 \pm 6.7 \text { events/hr.) } \\
\text {-Signiant increase in total sleepiness time and mean overnight O2 saturation } \\
\text { (402.1 } \pm 50.3 \text { t0 } 433.4 \pm 67.2 \mathrm{~min} \text {, and } 96.8 \pm 1.5 \text { to } 97.5 \pm 1.8 \%) \text {. }\end{array}$ \\
\hline $\begin{array}{l}\text { Hoxhas } \\
\text { S et } \\
\mathrm{al}^{19}\end{array}$ & $\begin{array}{l}\text { SRME with } 5 \mathrm{~m} \\
\text { follow up }\end{array}$ & $\begin{array}{l}\text { craniofacial/dental changes: } \\
\text {-significant increase in the nasopharyngeal area }(205.0 \pm 85.4-243.7 \pm \\
114.5 \mathrm{~mm}) \text { and total pharyngeal area }(750.1 \pm 168.9 \text { to } 858.7 \pm 179.6 \mathrm{~mm}) \text { in } \\
\text { the treatment group. } \\
\text {-significant increase in the intrecanine width }(31.9 \pm 2.69 \text { to } 36.39 \pm 2.98 \\
\text { mm), interpremolar width }(38.03 \pm 3.41 \text { to } 44.46 \pm 3.07 \mathrm{~mm}) \text { and intermolar } \\
\text { width ( } 47.77 \pm 4.07 \text { to } 54.4 \pm 3.26 \mathrm{~mm}) \text { on the dental arch model in the } \\
\text { treatment group. } \\
\text {-significant increase in the nasal width ( } 26.89 \pm 2.78-30.12 \pm 2.64 \mathrm{~mm}) \text {, } \\
\text { maxillary width ( } 55.12 \pm 6.5-59.15 \pm 4.55 \mathrm{~mm}) \\
\text { protein levels associated with OSA in serum urine and their relation to arch } \\
\text { width: } \\
\text {-serum Kallikerein (KLK) } 1 \text { showed a significant decrease after treatment } \\
\text { ( } 8.92 \pm 6.96 \text { to } 6.34 \pm 4.53 \text { ). } \\
\text {-significant increase in serum Orosomucoid (ORM) } 2 \text { ( } 2.58 \pm 2.07 \text { to } 3.40 \pm \\
2.18) \text { and a significant decrease in urine KLK } 1 \text { ( } 5.52 \pm 0.62 \text { to } 4.94 \pm 0.70) \\
\text { and Perlecan level }(6.30 \pm 1.18 \text { to } 5.03 \pm 0.96) \text { at C1 in control group }\end{array}$ \\
\hline
\end{tabular}

Table 3: Risk of bias assessment 


\begin{tabular}{|c|c|c|c|c|c|c|c|}
\hline \multirow[t]{2}{*}{ Study } & \multicolumn{2}{|c|}{ Selection bias } & \multirow{2}{*}{$\begin{array}{l}\text { Performance } \\
\text { bias } \\
\text { Blinding of } \\
\text { participants } \\
\text { and } \\
\text { personnel }\end{array}$} & \multirow{2}{*}{$\begin{array}{l}\text { Detection } \\
\text { bias } \\
\text { Blinding of } \\
\text { outcome } \\
\text { assessment }\end{array}$} & \multirow{2}{*}{$\begin{array}{l}\text { Attrition bias } \\
\text { Incomplete } \\
\text { outcome data }\end{array}$} & \multirow{2}{*}{$\begin{array}{l}\text { reporting } \\
\text { Selective } \\
\text { reporting. }\end{array}$} & \multirow{2}{*}{$\begin{array}{l}\text { Other } \\
\text { sources } \\
\text { of bias }\end{array}$} \\
\hline & $\begin{array}{l}\text { Random } \\
\text { sequence } \\
\text { generation. }\end{array}$ & $\begin{array}{l}\text { Allocation } \\
\text { concealment. }\end{array}$ & & & & & \\
\hline $\begin{array}{l}\text { Villa } \\
\text { MP et } \\
\text { al. }{ }^{13} \\
\end{array}$ & High & High & High & Unclear & $\begin{array}{l}\text { High: due to } \\
\text { withdrawal in } \\
\text { both groups }\end{array}$ & Low & - \\
\hline $\begin{array}{l}\text { Cozza } \\
\text { et al } 18\end{array}$ & High & High & High & Unclear & Low & Low & - \\
\hline $\begin{array}{l}\text { Pirelli } \\
\text { P et } \\
\mathrm{al}^{17} \\
\end{array}$ & High & High & High & Unclear & Low & Low & $\begin{array}{l}\text { No } \\
\text { control } \\
\text { group } \\
\end{array}$ \\
\hline $\begin{array}{l}\text { Villa } \\
\text { MP et } \\
\mathrm{al}^{16}\end{array}$ & High & High & High & Unclear & $\begin{array}{l}\text { High: } 2 \text { patients } \\
\text { were excluded } \\
\text { during } \\
\text { treatment. }\end{array}$ & Low & $\begin{array}{l}\text { No } \\
\text { control } \\
\text { group }\end{array}$ \\
\hline $\begin{array}{l}\text { Villa } \\
\text { MP et } \\
\mathrm{al}^{21} \\
\end{array}$ & High & High & High & Unclear & Low & Low & $\begin{array}{l}\text { No } \\
\text { control } \\
\text { group }\end{array}$ \\
\hline $\begin{array}{l}\text { Villa } \\
\text { MP } \\
\text { et }^{15} \\
\end{array}$ & High & High & High & Unclear & $\begin{array}{l}\text { High: } 5 \text { patients } \\
\text { were excluded } \\
\text { from analysis }\end{array}$ & Low & $\begin{array}{l}\text { No } \\
\text { control } \\
\text { group }\end{array}$ \\
\hline $\begin{array}{l}\text { Pirelli } \\
\text { P et } \\
\mathrm{al}^{14} \\
\end{array}$ & High & High & High & Unclear & $\begin{array}{l}\text { High: } 8 \text { patients } \\
\text { drop out }\end{array}$ & Low & $\begin{array}{l}\text { No } \\
\text { control } \\
\text { group }\end{array}$ \\
\hline $\begin{array}{l}\text { Villa } \\
\text { MP et } \\
\mathrm{al}^{20}\end{array}$ & High & High & High & Unclear & Low & Low & $\begin{array}{l}\text { No } \\
\text { control } \\
\text { group }\end{array}$ \\
\hline $\begin{array}{l}\text { Hoxhas } \\
\text { S et } \\
\mathrm{al}^{19}\end{array}$ & High & High & High & Unclear & Low & Low & - \\
\hline
\end{tabular}

Table 4: summery of individual studies. 


\begin{tabular}{|c|c|}
\hline $\begin{array}{l}\text { Author, } \\
\text { study } \\
\text { design: }\end{array}$ & Villa MP et al., 2002. Randomized controlled trail. ${ }^{13}$ \\
\hline Sample size: & 32 patients: 19 intervention group, 13 control group. \\
\hline Age: & range: $4-10$ yrs.; mean:7.1 \pm 2.6 yrs. \\
\hline $\begin{array}{l}\text { Type of } \\
\text { intervention: }\end{array}$ & Oral repositioning appliance \\
\hline Results: & 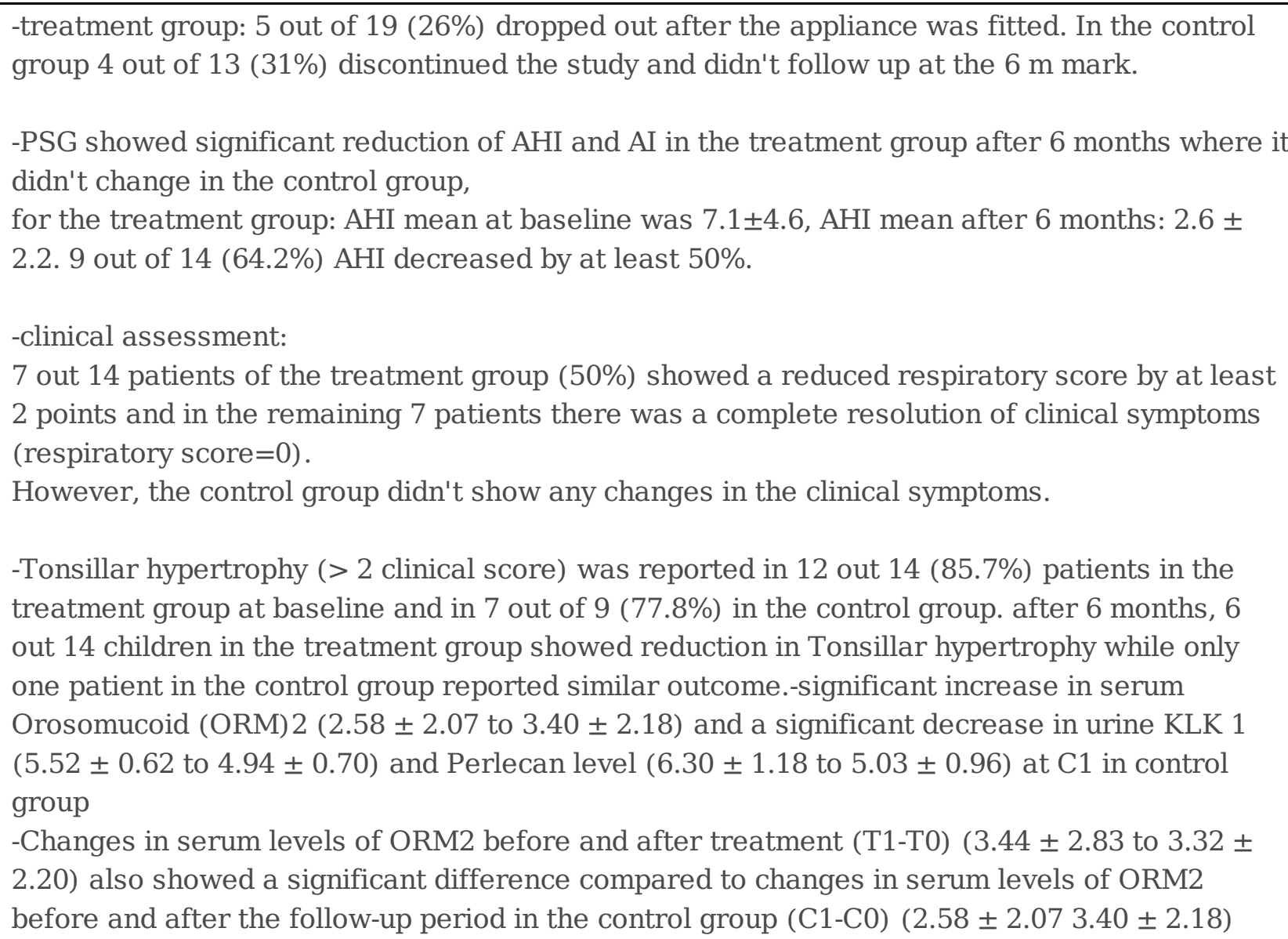 \\
\hline $\begin{array}{l}\text { Author, } \\
\text { study } \\
\text { design: }\end{array}$ & Cozza et al., 2004. Prospective clinical study ${ }^{18}$. \\
\hline Sample size: & 40 patients: 20 intervention group, 20 control group \\
\hline Age: & Intervention: Range: $4-8$ yrs., mean 5.9 yrs. Control: Range: $5-7$ yrs., mean 6 yrs. \\
\hline $\begin{array}{l}\text { Type of } \\
\text { intervention: }\end{array}$ & Modified monobloc MM \\
\hline Results: & $\begin{array}{l}\text { difference in the craniofacial morphology between OSA group and the control group: } \\
\text { higher ANB angle (skeletal class II) in OSA group vs control group (5.59-degree, } 2.9 \text { degree } \\
\text { respectively). } \\
\text { lower mandibular length in OSA group compared to control group ( } 58.82 \mathrm{~mm}, 65.4 \mathrm{~mm} \\
\text { respectively). } \\
\text { deeper overbite in OSA group compared to control group ( } 2.45 \mathrm{~mm}, 1.2 \mathrm{~mm} \text { respectively). } \\
\text { hyoid bone was located more superiorly in OSA group compared to control group (vertical } \\
\text { distance AH-SN } 85.18 \mathrm{~mm}, 91.2 \mathrm{~mm} \text { respectively). }\end{array}$ \\
\hline
\end{tabular}


Dental arch analysis revealed a narrower distance between the 1st and 2nd inter-molar primary mandibular region (30.4, 36.8mm in OSA group and 33, 38mm in the control group)

PSG after 6 months of MM showed a significant decrease in AHI in OSA group from 7.88 at baseline to 3.66

Reduced daytime sleepiness and improved quality of sleep was observed after $6 \mathrm{~m}$ of MM therapy in OSA group (ESS score reduced from $15.2 \pm 4.9$ to $7.1 \pm 2$ )

\begin{tabular}{l|l}
\hline $\begin{array}{l}\text { Author, } \\
\text { study } \\
\text { design: }\end{array}$ & Pirelli P et al, 2004. Prospective clinical study ${ }^{17}$. \\
\hline Sample size: & 31 patients (no control group) \\
\hline Age: & Range: 6-12 yrs., mean: 8.68 yrs. \\
\hline $\begin{array}{l}\text { Type of } \\
\text { intervention: }\end{array}$ & Rapid maxillary expansion \\
\hline
\end{tabular}

Results:

31 patients were included in this study and the outcomes were measured in 3 phases; at T0: before the orthodontic treatment, At T1: 4-6 weeks after the beginning of RME and at T2: 4 months after the orthodontic treatment completion.

At TO:

extraoral examination revealed that All patients had flattening of the mid third of the face, there was 9 patients with skeletal class I, 14 patients presented with skeletal class II and 8 patients had skeletal class III

Intraoral examination showed a constriction of the maxilla due to high and narrow palatal arch.

ENT assessment using Active anterior rhinometry revealed that a pathological nasal resistance $>1.8$ pascal / cubic cm of water with bilateral breathing difficulties in 26 patients and unilateral nasal obstruction in 5 patients.

PSG showed an elevated AHI with a mean of 12.2 events/hr. and a range of 5.7 to 21.1 events/hr.

the study population was subdivided into group A, B and C based on their AHI readings. (subgroup A: 7 patients with $\mathrm{AHI}>5$ and $<10$, subgroup B: 20 patients with $\mathrm{AHI}=10$ and $<15$, subgroup C: 4 patients with $\mathrm{AHI}=15$ )

AT T1:

ENT assessment revealed a normalized nasal resistance in 21 out 26 patients with unilateral resistance and in all 5 patients with unilateral resistance.

PSG 29 out of the 31 children had an AHI < 5 events/hr. the remaining 2 children (both were in subgroup C) had AHI of 6.3 and 8.1 events/hr. from initial of 19.6 and 21.1 events/hr.

AT T2:

ENT assessment and PSG showed a significant improvement from T1 compared to T1:

Anterior rhinometry showed a decrease in nasal resistance with the absence of pathological findings. 


\begin{tabular}{|c|c|}
\hline & $\begin{array}{l}\text { PSG: significant reduction in AHI from T0-T2 }(12.18 \pm 2.6 \text { to } 0.4 \pm 1.1 \text { events } / \mathrm{hr} \text {. }), \mathrm{AHI}<1 \mathrm{in} \\
\text { all children. } \\
\text { Anatomical changes in upper jaw and nasal septum including: } \\
\text {-expansion of maxilla and mandible with the mean cross-sectional increase of } 4.32 \pm .7 \mathrm{~mm} \\
\text { - increase upper molar distance }(3.89 \pm .3) \\
\text {-midpalate opening and inter incisive space opening }(2.97 \pm .2 \mathrm{~mm}) \\
\text {-mean increase in the nasal pyriform opening of } 1.3 \pm .3 \mathrm{~mm}\end{array}$ \\
\hline $\begin{array}{l}\text { Author, } \\
\text { study } \\
\text { design: }\end{array}$ & Villa MP et al., 2007. Prospective clinical study ${ }^{16}$ \\
\hline Sample size: & 16 patients (no control group) \\
\hline Age: & Range: $4.5-10.5$ yrs. mean $6.9 \pm 2.2$ yrs. \\
\hline $\begin{array}{l}\text { Type of } \\
\text { intervention: }\end{array}$ & RME with 12 months follow up \\
\hline Results: & $\begin{array}{l}14 \text { out of the } 16 \text { patients completed the trail. } \\
\text { PSG evaluation: } \\
\text {-mean AHI showed a significant decrease from } 5.8 \pm 6.8 \text { to } 1.5 \pm 1.6 \text { events } / \mathrm{hr} \text {. } \\
\text {-AHI showed more improvement in patients with deep and retrusive bites compared to patients } \\
\text { with cross-bite }(6.7 \pm 8.4 \text { vs } 1 \pm 1 \text { evets/hr. and } 4.3 \pm 2.1 \text { vs } 2.5 \pm 2.2 \text { events/hr.) } \\
\text {-OHI and arousal index OI also showed significant improvement ( } 3.1 \pm 3.2 \text { vs } .9 \pm 1.3 \text { and } 17.2 \\
\pm 3.5 \text { vs } 9.2 \pm 1.6 \text { respectively) } \\
\text {-AHI didn't change after RME in } 2 \text { patients; the } 1 \text { st was a boy who had undergone } \\
\text { adenotonsillectomy } 2 \text { yrs. before RME, right convex deviation of the nasal septum and a } \\
\text { monolateral cross bite. His AHI before RME was } 1.4 \text { vs } 1.6 \text { after. } \\
\text { the other case was a boy with recurrent upper respiratory infections, reduced epi-pharyngeal } \\
\text { airway lumen due to adenoid vegetation and deep bite. His AHI was } 1.5 \text { before RME vs } 3.2 \\
\text { after. } \\
\text { Oto-rhinolaryngologic examination: } \\
\text {-mild tonsillar hypertrophy (clinical score }+2 \text { ) in } 5 \text { out of the } 14 \text { patients. The AHI mean was } 5.6 \\
\text { vs } 1.0 \text { event/hr. before vs after RME. } \\
\text {-moderate tonsillar hypertrophy (clinical score }+3 \text { ) in } 5 \text { out of } 14 \text { patients. } \\
\text {-severe tonsillar hypertrophy (clinical score }+4 \text { ) in } 1 \text { patient. AHI score was } 6.2 \text { vs } 2.3 \\
\text { events/hr. (before vs after RME) } \\
-3 \text { patients had no tonsillar hypertrophy. } \\
\text {-3 patients underwent adenotonsillectomy } 2 \text { yrs. Before RME. } \\
\text { Maxillary arch expansion: } \\
\text {-mean maxillary expansion of } 3.7 \pm .7 \text { interchained diameter and } 5 \pm 2.2 \text { in premolar diameter } \\
\text {-significant decrease in the severity of the symptoms. Brouillette questionnaire: mean clinical } \\
\text { score improve from } 8.2 \pm 4 \text { vs } 4.2 \pm 2.9 \text {. }\end{array}$ \\
\hline $\begin{array}{l}\text { Author, } \\
\text { study } \\
\text { design: }\end{array}$ & Villa MP et al., 2011. Prospective clinical study ${ }^{21}$. \\
\hline Sample size: & 10 patients (no control group) \\
\hline
\end{tabular}

Page 19/25 


\begin{tabular}{|c|c|}
\hline Age: & Range: $4-8$ yrs. Mean: $6.6 \pm 2.1$ yrs. \\
\hline $\begin{array}{l}\text { Type of } \\
\text { intervention: }\end{array}$ & RME with 36 m follow up \\
\hline Results: & 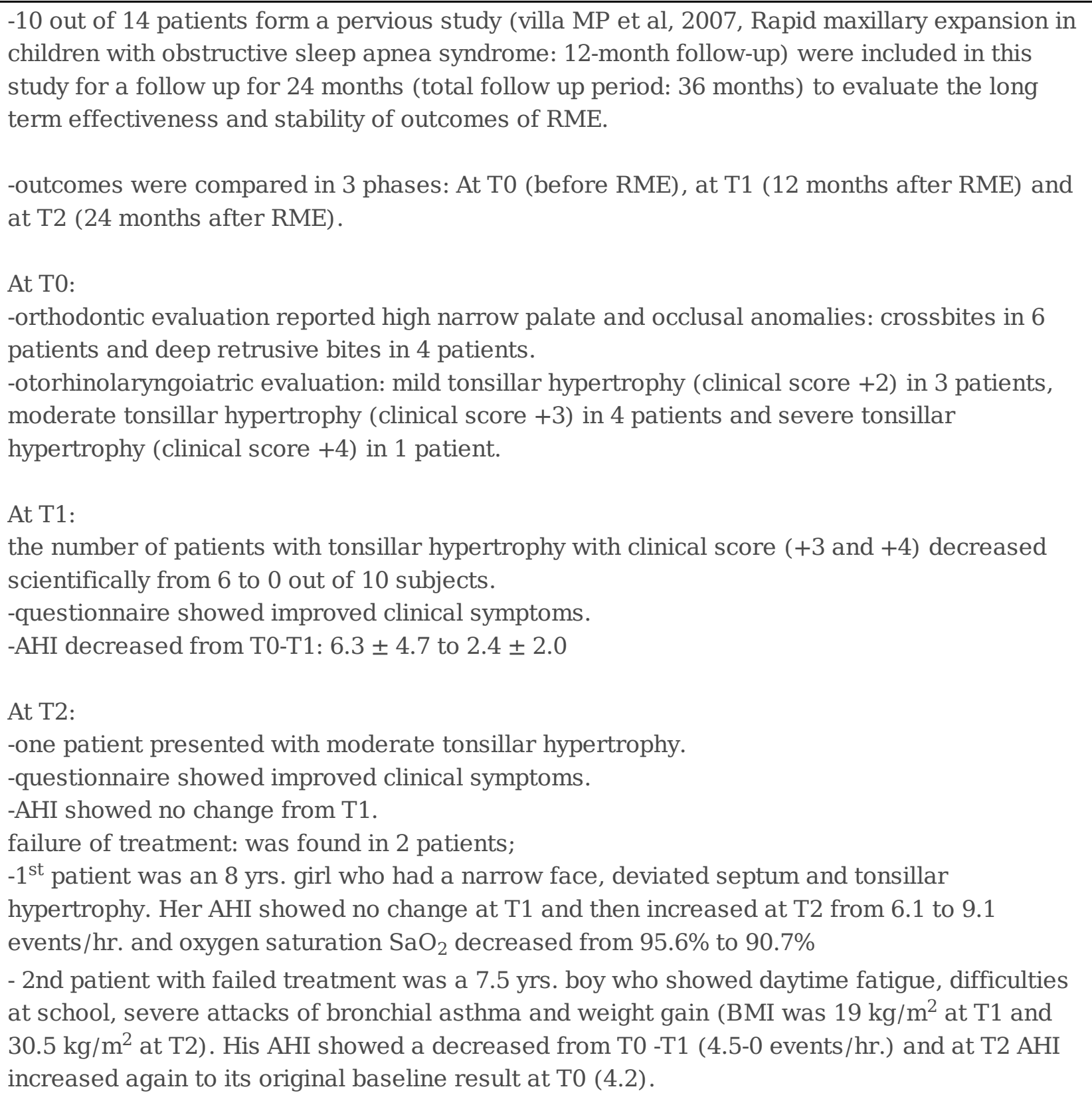 \\
\hline $\begin{array}{l}\text { Author, } \\
\text { study } \\
\text { design: }\end{array}$ & Villa MP et al., 2014. Prospective clinical study ${ }^{15}$. \\
\hline Sample size: & $\begin{array}{l}52 \text { patients: } 25 \text { treatment group } 1 \text { (adenotonsillectomy), } 22 \text { treatment group } 2 \text { (RME), } 5 \\
\text { treatment group } 3 \text { (both) }\end{array}$ \\
\hline Age: & 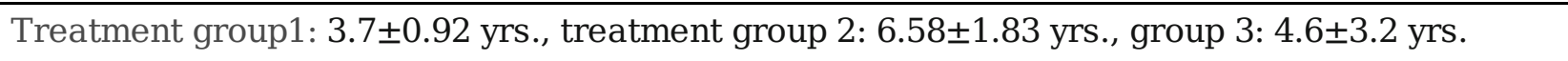 \\
\hline $\begin{array}{l}\text { Type of } \\
\text { intervention: }\end{array}$ & Adenotonsillectomy, RME, Both \\
\hline Results: & $\begin{array}{l}\text { study population }(\mathrm{n}=52) \text { was divided into } 3 \text { group: } \\
\text {-Group } 1 \text { consisted of } 25 \text { children with tonsillar enlargement and AHI }>5 \text { events } / \text { hr. underwent } \\
\text { adenotonsillectomy. }\end{array}$ \\
\hline
\end{tabular}

Page 20/25 
-Group2 consisted of 22 children older than 4 yrs., AHI < 5 events/hr. presented with high arch palate and/or malocclusion underwent RME.

-Group 3 consisted of 5 children who underwent both AT and RME

-out of 52 subjects 47 were included in the study analysis ( 5 children from group 3 were excluded from the analysis)

\section{At TO (before treatment)}

-group 2 subjects showed higher: age, disease duration and BMI compared to group 2

( $6.58 \pm 1.83$ vs $3.7 \pm 0.92$ yrs., $4.10 \pm 1.99$ vs $2.14 \pm 1.16$ yrs., $18.82 \pm 3.44$ vs $15.75 \pm 1.82)$

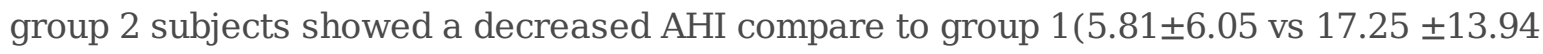
events/hr.)

-21 out of 25 children in group 1 showed dental malocclusion and/or high arch palate and 9 out of 22 children in group 2 showed Aden tonsillar enlargement (grade 3 of Friedman scale).

\section{At T1 (after treatment):}

-Group 1:

BMI, mean overnight saturation showed a significant increase from T0-T1 $(47.05 \pm 13.94$ to $81.35 \pm 26.49$ and $96.11 \pm 2.68$ to $97.5 \pm 1.14$ ) and AHI and AI showed a significant decrease from T0-T1 (17.25 \pm 13.94 to $1.79 \pm 1.82$ and $20.87 \pm 5.66$ to $14.5 \pm 6.51)$

$\mathrm{BMI}$ percentage at $\mathrm{T} 0$ correlate negatively with the $\Delta \mathrm{AHI}$ and $\mathrm{AHI}$ correlate positively with $\triangle \mathrm{AHI}$

-Group 2:

mean overnight saturation and total sleep time showed significant increase from T0-T1

$(96.56 \pm 1.47$ to $97.42 \pm 1.84$ and $6.64 \pm .89$ to $7.47 \pm .92)$

AHI showed a significant decrease from T0-T1 (5.1 \pm 6.05 to $2.64 \pm 3.11$ events/hr.)

disease duration correlated negatively with $\triangle \mathrm{AHI}$

-efficiency of treatment measured by $\Delta$ AHI was higher in group 1 compared to group2 84.01\% vs $36 \%$ respectively.

-28 children showed residual disease AHI > 1 after treatment with no statistically significant difference between groups (56\% in group 1 and 63\% in group 2). 50\% of children with residual disease in group 2 had severe tonsillar enlargement.

-Group 3: mean disease duration 2.8 \pm 3.1 , mean age at onset of disease $1.8 \pm 97$. subjects showed a significant decrease in AHI from T0-T1 (10.14 \pm 7.25 to $.88 \pm .95)$

\begin{tabular}{|l|l|}
\hline $\begin{array}{l}\text { Author, } \\
\text { study } \\
\text { design: }\end{array}$ & Pirelli P et al., 2015. Prospective clinical study ${ }^{14}$. \\
\hline Sample size: & 31 patients (no control group) \\
\hline Age: & Range: 6-12 yrs. Mean: 8.68 yrs. \\
\hline $\begin{array}{l}\text { Type of } \\
\text { intervention: }\end{array}$ & RME with 12 yrs. follow up \\
\hline Results: & $\begin{array}{l}\text { 8 subjects dropped out during the follow up period. the final sample consisted of } 23 \text { subjects } \\
\text { (73\% of the initial sample) }\end{array}$ \\
\hline
\end{tabular}




\begin{tabular}{|c|c|}
\hline & $\begin{array}{l}\text { - an opening in the inter incisive space }(2.95 \pm .3 \mathrm{~mm} \text { ) was present. } \\
\text {-PSG showed a significant decrease in } \mathrm{AHI} \text { form } 12.2 \pm 2.6 \text { to } .4 \pm 1.6 \text { events } / \mathrm{hr} \text {. and a } \\
\text { significant increase in } \mathrm{SaO} 2 \text { from } 78.9 \pm 8.6 \% \text { to } 95.1 \pm 1.9 \% \text {. } \\
\text {-complete resolution of clinical symptoms. } \\
\text { At } 12 \text { yrs. follow up: } \\
\text { - no clinical symptoms (ESS mean score } 3 \pm 1 \text { ) } \\
\text {-PSG showed values within the normal ranges with no significant changes. } \\
\text {-CT scan confirmed the stability and maintaince of anatomical changes induced by RME } \\
\text { (maxillary base width, distance of pterygoid process) }\end{array}$ \\
\hline $\begin{array}{l}\text { Author, } \\
\text { study } \\
\text { design: }\end{array}$ & Villa MP et al., 2015. Prospective clinical study ${ }^{20}$. \\
\hline Sample size: & 40 patients \\
\hline Age: & Range:4.3 -10.5 yrs. Mean: 6.3 \pm 1.6 yrs. \\
\hline $\begin{array}{l}\text { Type of } \\
\text { intervention: }\end{array}$ & $\mathrm{RME}$ \\
\hline Results: & 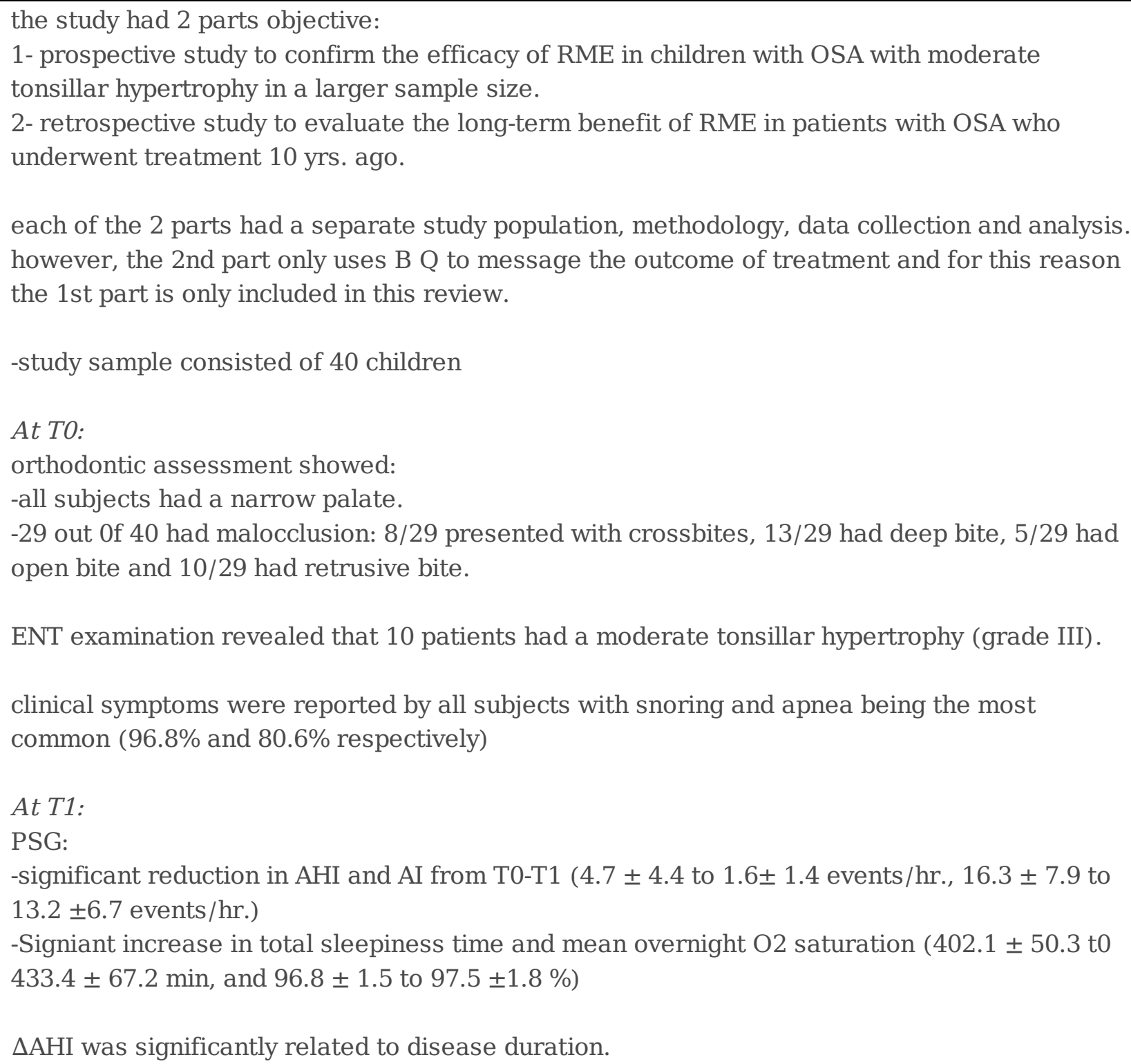 \\
\hline
\end{tabular}


according to the response to the treatment the sample was divided into 2 groups: responders and nonresponses

-responders showed an AHI decrease $>20 \%$ and consisted of 34 children (AHI at T0: $5.2 \pm 4.7$ events/hr., AHI at T1: $1.4 \pm 1.3$ events/hr.)

-nonresponses showed AHI decrease $<20 \%$ and consisted of 6 children (AHI at T0: $2.1 \pm 1.3$

events/hr., AHI at T1: $2 . \pm 1.3$ events/hr.)

-duration of disease was lower in responders compared to nonresponses ( $2.5 \pm 1.4$ yrs. vs 4.8 \pm 1.9 )

-age at the onset of disease was higher in responders compered to nonresponses (3.8 \pm 1.5

yrs. vs $2.3 \pm 1.9$ yrs.)

-NBA (cranial base angle) was higher in nonresponses compered to responders (138.01 \pm 6.49 vs $132.05 \pm 4.85)$

-23 out of 40 patients showed a residual OSA after treatment (defined as AHI > 1 after RME). no significant difference was noted between children with residual disease and children without

\begin{tabular}{l|l}
\hline $\begin{array}{l}\text { Author, } \\
\text { study } \\
\text { design: }\end{array}$ & Hoxhas S et al., 2018. Prospective clinical study ${ }^{19}$. \\
\hline
\end{tabular}

Sample size: 30 patients:15 treatment group, 15 control group

Age: $\quad$ Mean: $12.27 \pm 1.93$ yrs., mean: $11.46 \pm 2.06$ yrs.

Type of $\quad$ SRME with 5 months follow up

intervention:

\begin{tabular}{l|l} 
Results: & the sample was divided into 2 groups: treatment group and a control group.
\end{tabular}

At C0-T0

-all included children had malocclusion with narrow maxilla.

-pretreatment parental questionnaire revealed that all children suffered from snoring.

after SRME treatment and 5 months follow up:

-sleep test showed a significant decrease in AHI in treatment group from T0-T1 (2.5 \pm 1.12 to $1.79 \pm 1.05$ events/hr.) and also a significant decrease in control group from C0-C1 (2.67 \pm 1.32 to $1.8 \pm 1.08$ events/hr.)

craniofacial/dental changes:

-significant increase in the nasopharyngeal area $(205.0 \pm 85.4-243.7 \pm 114.5 \mathrm{~mm})$ and total pharyngeal area $(750.1 \pm 168.9$ to $858.7 \pm 179.6 \mathrm{~mm})$ in the treatment group.

-significant increase in the intrecanine width (31.9 \pm 2.69 to $36.39 \pm 2.98 \mathrm{~mm}$ ), interpremolar width (38.03 \pm 3.41 to $44.46 \pm 3.07 \mathrm{~mm})$ and intermolar width $(47.77 \pm 4.07$ to $54.4 \pm 3.26$ $\mathrm{mm}$ ) on the dental arch model in the treatment group.

-significant increase in the nasal width $(26.89 \pm 2.78-30.12 \pm 2.64 \mathrm{~mm})$, maxillary width (55.12 $\pm 6.5-59.15 \pm 4.55 \mathrm{~mm})$

protein levels associated with OSA in serum urine and their relation to arch width: -serum kallikerein (KLK) 1 showed a significant decrease after treatment (8.92 \pm 6.96 to $6.34 \pm$ 4.53).

-significant increase in serum orosomucoid (ORM) $2(2.58 \pm 2.07$ to $3.40 \pm 2.18)$ and a significant decrease in urine KLK 1 (5.52 \pm 0.62 to $4.94 \pm 0.70)$ and perlecan level $(6.30 \pm 1.18$ to $5.03 \pm 0.96)$ at $\mathrm{C} 1$ in control group

Page 23/25 
-Changes in serum levels of ORM2 before and after treatment (T1-T0) (3.44 \pm 2.83 to $3.32 \pm$ 2.20) also showed a significant difference compared to changes in serum levels of ORM2 before and after the follow-up period in the control group (C1-C0) $(2.58 \pm 2.073 .40 \pm 2.18)$ -there was a negative correlation between serum uric acid and interpremolar width. -there was an inverse relation between ORM 2, KLK 1 and uric acid and intermolar width

\section{Figures}

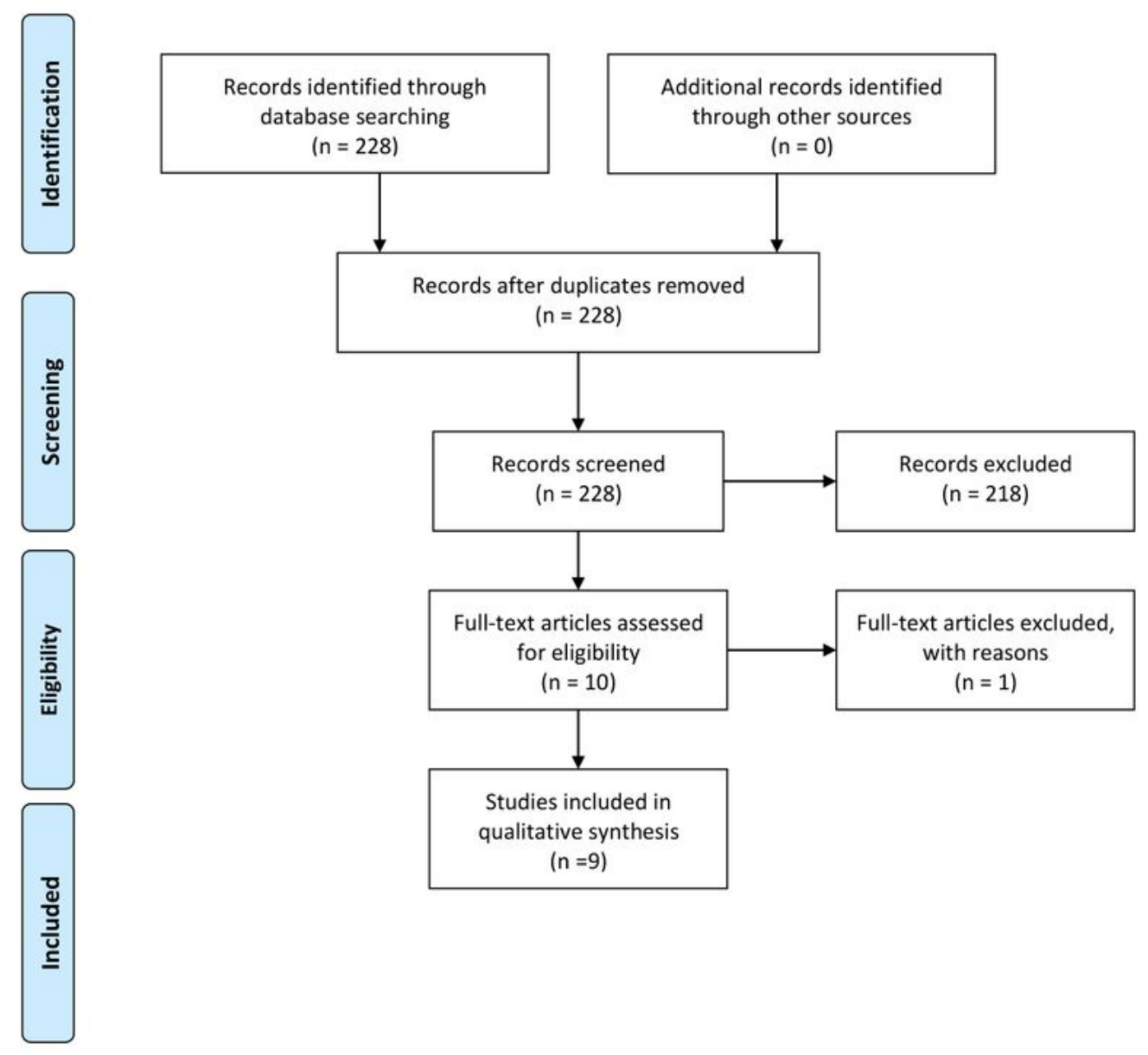

From: Moher D, Liberati A, Tetzlaff J, Altman DG, The PRISMA Group (2009). Preferred Reporting /tems for Systematic Reviews and MetaAnalyses: The PRISMA Statement. PLoS Med 6(7): e1000097. doi:10.1371/journal.pmed1000097

For more information, visit www.prisma-statement.org. 
Figure 1

Prisma flow chart for study selection 